\title{
OZONE EFFECTS ON TOXICITY OF WHEAT GRAIN AND GRAIN MIXTURES
}

\author{
Valentina Avdeeva, Galina Starodubtseva, Julia Bezgina, Elena Zorina, Alexander Lysakov \\ Stavropol State Agrarian University, Russia \\ avdeeva_vn@mail.ru,sgp_starodubtseva@mail.ru, juliya.bezgina@mail.ru, zeb26@mail.ru, \\ s_lysakov@mail.ru
}

\begin{abstract}
Wheat grain is one of the most valuable crops, as it is rich in gluten proteins and other valuable substances. Currently, the food industry and the grain market place high demands on the quality of wheat grain. However, individual batches of grain have toxic properties as a result of the content of heavy metals, harmful mycoflora. Grain mixtures can be even more toxic due to their fine structure. In this regard, the search for effective ways to reduce the overall toxicity of grain and grain mixtures is of scientific and practical interest. One of the most environmentally promising methods of grain disinfection is ozonization. A number of experiments on the effects of ozone on the toxicity of grain and grain mixtures have been conducted at the Stavropol State Agrarian University. To determine the objective picture of the state of grain and feed in the research laboratory using biotesting, 40 samples of wheat grain and 94 samples of grain mixtures from different agroclimatic zones of Russia were examined for general toxicity. As a result, it was found that nineteen samples of forty grains had moderate and high toxicity. Thus, the assumption was confirmed about the need to find ways to reduce the toxicity of grain and forage in order to ensure the safety of feeding animals and poultry. To accomplish this goal, we conducted a series of experiments on disinfection of wheat grain and grain mixtures with ozone in various modes. The ozone concentration was determined using a Cyclone-5.41 gas analyzer. The processing of wheat and grain mixtures was carried out with an ozone generator "Ozone-60P" with a plant capacity of $60 \mathrm{~g} \cdot \mathrm{h}^{-1}$. As a result of the research, the effect of ozone on the reduction of the toxicity of wheat grain and grain mixtures was found. The article presents the optimal modes of disinfection of wheat and grain mixtures with ozone to reduce the overall toxicity.
\end{abstract}

Keywords: ozone, wheat grain, toxicity, disinfection.

\section{Introduction}

The grain market is the core of the development of the agrarian economy and its condition determines the quality of the country's agrifood policy [2]. Today the grain market can serve as a peculiar development model for other markets of agricultural products, raw materials and food. Therefore, grain farming requires priority attention to its development from the state [5]. Increased demand for grain and expected increase in prices for it contribute to the growth of competition in the world. And in this regard, a special place is occupied by the issue of the quality of grain products and environmental performance [4]. The main types of grain crops on the world market are wheat, barley, oats, buckwheat, peas, corn and rice. Wheat grain is one of the most valuable and high-yielding grain crops, since it is rich in gluten proteins and other valuable substances [6].

Currently, the food industry and the grain market place high demands on the quality of wheat grain [9]. However, not all grain meets the requirements of the State Standard, some have toxic properties as a result of the content of heavy metals and harmful microflora in them. In this regard, the scientific and practical interest is the search for effective ways to reduce the overall toxicity of grain and grain mixtures. One of the most environmentally promising methods of grain disinfection is ozonization [7]. Ozonation is widely used both for disinfecting agricultural products and improving the sowing qualities of crops [8]. The use of ozonized air in agricultural production was carried out by scientists Aboltins A., Palabinskis J., Kince T., Galoburda R., Klava D., Blija A., Kerch G., Borodin I.F.,Starodubtseva G. P., Oskin S. V., Shevchenko A.A., Ksonz N.V., Rubtsova E.I.

The aim of our research is to search for modes of disinfection of grain and grain mixtures in order to reduce their toxicity and improve the environmental performance of products.

\section{Materials and methods}

Based on the work of scientists in the field of ozone technologies, a number of studies have been conducted on the effects of ozone on the toxicity of grain and grain mixtures in the Educational Scientific Testing Laboratory of the Stavropol State Agrarian University. To determine the objective picture of the state of grain and feed in the laboratory using the biotesting method, we studied the total toxicity of 40 samples of winter wheat grain and 94 samples of grain mixtures from different 
agroclimatic zones of the country. This method is designed to determine the toxicity of samples of various water extracts by the reaction of ciliates using Paramecium caudatum (hereafter the ciliates) as the test object. The parameters of the behavioral response of ciliates were determined using the device "Biotester-2", shown in Fig. 1.

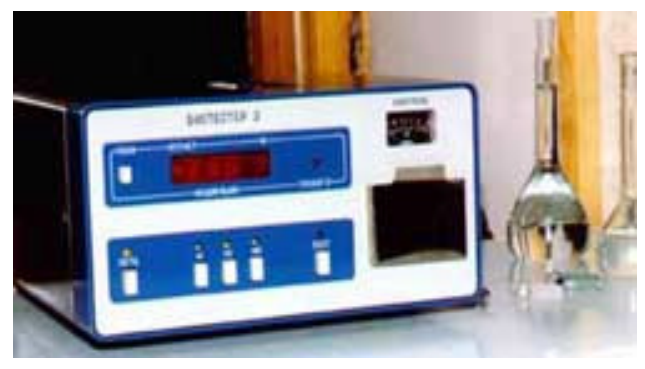

\section{Fig. 1. Toxicity tester, biotester-2 concentration meter}

Quantitative assessment of the parameter of the test reaction, which characterizes the toxic effect, is made by calculating the ratio of the number of ciliates observed in the control and test samples, and is expressed as a dimensionless quantity - toxicity index $(\mathrm{T})$ : the index of permissible toxicity -0.00 0.40 ; index of moderate toxicity $-0.41-0.70$; high toxicity index -0.71 and higher.

As a result of the research, it was found that nineteen samples of grain from forty had moderate and high toxicity. Studies of grain mixtures led to the following results: 38 samples had permissible toxicity, 35 samples - moderate toxicity, 21 samples - high toxicity. Feed with high toxicity should not be used, as it causes poisoning of animals. It was undesirable to use feed with moderate toxicity.

Thus, the assumption was confirmed about the need to find ways to reduce the toxicity of grain and forage in order to ensure safety of feeding animals and poultry. To accomplish this goal, we conducted a series of experiments on disinfecting wheat and grain mixtures with ozonized air in various modes in the Educational - Scientific Testing Laboratory. Since the result of ozonation in the study of the effect of the ozone-air mixture on grain and feed is influenced by several factors, we have introduced the concept of "treatment dose" [3]. The dose of treatment is calculated by the formula

$$
D=c \cdot t
$$

where $D$ - treatment dose, $\mathrm{g} \cdot \mathrm{s} \cdot \mathrm{m}^{-3}$;

$c$ - ozone concentration, $\mathrm{g} \cdot \mathrm{m}^{-3}$

$t$ - seed treatment time (exposure), s.

The concentration of ozone was determined using a gas analyzer "Cyclone-5.41".

The processing of wheat and grain mixtures was carried out with an industrial ozone generator "Ozone-60P" with a plant capacity of $60 \mathrm{~g} \cdot \mathrm{h}^{-1}$. Ozone dose control was carried out by increasing the exposure of grain processing. For the purity of the experiments, statistical data processing by the method of variance analysis was carried out for a two-factor PC experiment (D.A. Dospekhov, 1985) [2]. Factor A - ozone doses ranged from $2 \mathrm{~g} \cdot \mathrm{s} \cdot \mathrm{m}^{-3}$ to $630.0 \mathrm{~g} \cdot \mathrm{s} \cdot \mathrm{m}^{-3}$. Factor B - exposure of the samples was one day. The samples were tested for general toxicity before and after ozone treatment. The experiments were carried out in six replicates.

\section{Results and discussion}

Treatment of wheat with doses of up to $350 \mathrm{~g} \cdot \mathrm{s} \cdot \mathrm{m}^{-3}$ did not lead to the desired result. Ozone - air treatment turned out to be more effective in the mode with a dose of ozone of $370.0 \mathrm{~g} \cdot \mathrm{s} \cdot \mathrm{m}^{-3}$. As a result of processing the wheat grain in the optimal mode $\left(370.0 \mathrm{~g} \cdot \mathrm{s} \cdot \mathrm{m}^{-3}\right)$, the grain toxicity index decreased by $26.0-28.0$ units. Increasing the ozone dose to $630.0 \mathrm{~g} \cdot \mathrm{s} \cdot \mathrm{m}^{-3} \mathrm{did}$ not contribute to a further significant decrease in the toxicity of the grain. The results of processing grain of wheat in the optimal modes are presented in Table 1.

In parallel with disinfection of wheat grain, research was carried out on the effect of the ozone air mixture on the toxicity of grain mixtures of various compositions. All samples of grain mixtures were exposed to ozone treatment on an "Ozone-60P"ozonizer. Ozone doses ranged from $2 \mathrm{~g} \cdot \mathrm{s} \cdot \mathrm{m}^{-3}$ to $630.0 \mathrm{~g} \cdot \mathrm{s} \cdot \mathrm{m}^{-3}$. The samples were checked for general toxicity before ozone treatment and after 
disinfection. Doses of 370 and $630 \mathrm{~g} \cdot \mathrm{s} \cdot \mathrm{m}^{-3}$ were effective. The results of processing of grain mixtures in optimal modes are presented in Table 2.

Effect of ozone on the level of grain toxicity of winter wheat

Table 1

\begin{tabular}{|c|c|c|c|c|c|c|}
\hline \multirow[b]{3}{*}{ 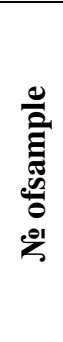 } & \multicolumn{6}{|c|}{ Option } \\
\hline & \multicolumn{2}{|c|}{ Control } & \multicolumn{2}{|c|}{$\begin{array}{l}\text { Ozone dose } \\
370 \mathrm{~g} \cdot \mathrm{s} \cdot \mathrm{m}^{-3}\end{array}$} & \multicolumn{2}{|c|}{$\begin{array}{l}\text { Ozone dose } \\
630 \mathrm{~g} \cdot \mathrm{s} \cdot \mathrm{m}^{-3}\end{array}$} \\
\hline & 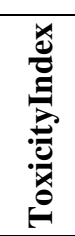 & 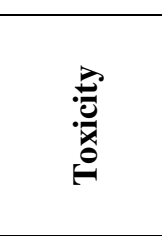 & 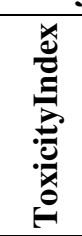 & 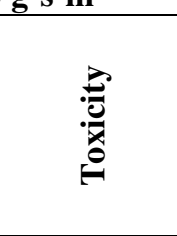 & 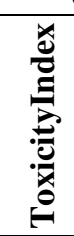 & 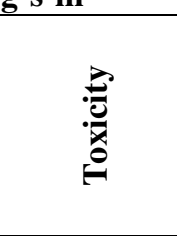 \\
\hline 1 & 0.66 & moderate & 0.31 & permissible & 0.31 & permissible \\
\hline 2 & 0.89 & high & 0.72 & moderate & 0.72 & moderate \\
\hline 3 & 0.77 & high & 0.49 & moderate & 0.48 & moderate \\
\hline 4 & 0.57 & moderate & 0.38 & permissible & 0.37 & permissible \\
\hline
\end{tabular}

Table 2

Effect of ozone-air treatment of grain mixtures on the level of toxicity of studied samples

\begin{tabular}{|c|c|c|c|c|c|c|}
\hline \multirow[b]{2}{*}{ 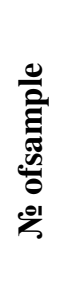 } & \multicolumn{2}{|c|}{ Control } & \multicolumn{2}{|c|}{$\begin{array}{c}\text { Ozone } \\
\text { dose } 370 \mathrm{~g} \cdot \mathrm{s} \cdot \mathrm{m}^{-3}\end{array}$} & \multicolumn{2}{|c|}{$\begin{array}{l}\text { Ozone dose } \\
630 \mathrm{~g} \cdot \mathrm{s} \cdot \mathrm{m}^{-3}\end{array}$} \\
\hline & 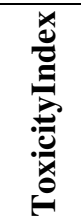 & 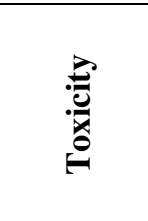 & 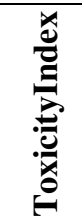 & 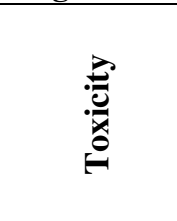 & 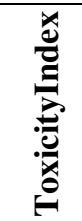 & 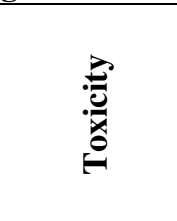 \\
\hline 1 & 0.90 & high & 0.61 & moderate & 0.61 & moderate \\
\hline 2 & 0.48 & moderate & 0.31 & permissible & 0.31 & permissible \\
\hline 3 & 0.92 & high & 0.63 & moderate & 0.63 & moderate \\
\hline
\end{tabular}

The table shows that disinfection of grain mixtures with an ozone dose of $370 \mathrm{~g} \cdot \mathrm{s} / \mathrm{m}^{3}$ allowed to significantly reduce toxicity and transfer the first and third samples from the high toxicity category to moderate toxicity, the second sample of the grain mixture from the moderate toxicity category turned into permissible toxicity. A further increase in the decontamination parameters did not reduce the toxicity of the samples.

\section{Conclusions}

Thus, the laboratory experiments to study the effect of the ozone-air flow on reducing the toxicity of wheat and grain mixtures suggest that ozone treatment affects the reduction of toxicity of wheat grain and grain mixtures to varying degrees, depending on the processing dose of the studied material. To reduce the toxicity of grain and grain mixes, the optimal dose of ozone is $376.0 \mathrm{~g} \cdot \mathrm{s} / \mathrm{m}^{3}$.

The toxicity of grain and grain mixtures largely depends on the number of infections and the ratio of pathogenic fungi. In order to destroy harmful mycobiota the Stavropol State Agrarian University has conducted long-term experiments to combat harmful fungi and is currently developing an integrated system for processing disinfection of grain crops.

\section{References}

[1] Авдеева В. Н. Применение экологических методов подавления патогенной микофлоры зерна озимой пшеницы при хранении (The use of ecological methods for suppression of pathogenic microflora of winter wheat grain during storage). Diss.cand.agr. sciences.V.N. Avdeeva. Stavropol, 2009. (In Russian).

[2] Авдеева В. Н. Применение экологических методов тподавления патогенной микофлоры зерна озимой пшеницы при хранении (The use of ecological methods for suppression of 
pathogenic microflora of winter wheat grain during storage). Author diss. cand. agr. sciences. V.N. Avdeeva. Stavropol, 2009. - 24 p. (In Russian).

[3] Avdeeva V.N., Antonov S.N., Molchanov A.G., Devederkin I.V.Disinfecting of winter wheat grain with electrophysical factors. Engineering for rural development, Gelgava Latvia, 2017, pp. 323-327.

[4] Шевченко А. А. Влияние озона на зерновые культуры / А. А. Шевченко, Е. А. Сапрунова, Р. С. Шхалахов // Физико-технические проблемы создания новых технологий в агропромышленном комплексе (The influence of ozone on grain crops / A. A. Shevchenko, E. A. Saprunova, R. S. Shkhalakhov // Physical and technical problems of creating new technologies in the agro-industrial complex). ProceedingsofInternationalconferenceof SSAU, 2003. pp. 645646. (In Russian).

[5] Трухачёв В.И., Авдеева В.Н., Стародубцева Г.П., Безгина Ю.А. Снижение токсичности зерна и кормов, поражённых микотоксинами. (Reducing the toxicity of grain and fodder affected by mycotoxins). Ruusianjournal : Agrarian science. 2007. No 5. pp.13-14. (In Russian).

[6] Kince T., Galoburda R., Klava D., Blija A., Kerch G. Effect of processing on microbial safety, total phenolic content and radical scavenging activity of germinated hull-less barley flakes. Journal of Food, Agriculture and Environment, 2017.

[7] Aboltins A., Palabinskis J., Lauva A. Grain active ventilation using ozonized air, 2010. ActaHorticulturae.

[8] Shutko A. P., Shek E. G., Tuturzhans L. V., Mikhno L. A., Ustimov D. V. Mycobiota Grains Of Winter Wheat, Depending On The Fungicidal Treatment. Research journal of pharmaceutical biological and chemical sciences. 2018. Vol. 9. Is. 6. pp. 1641-1644.

[9] Okrut S. V., Mandra Y. A., Stepanenko E. E., Zelenskaya T. G., Gudiev O. Yu. Application Of Physical And Chemical Methods In The Assessment Of The Ecological State Of The Environment Of Urbanized Areas. Research journal of pharmaceutical biological and chemical sciences. 2018. Vol. 9. Is. 4. pp. 660-665.

[10] Pashkova E. V., Bezgina Yu. A., Shipulya A. N., Volosova E. V., Mikhno L. A. GrowthStimulating Preparations Based On Lactose-Containing Raw Materials Into Technologies Of Grain Crops Cultivation. Research journal of pharmaceutical biological and chemical sciences. 2018. Vol. 9. Is. 4. pp. 1105-1109. 